\title{
Intracranial hemangiopericytoma showing excellent uptake on arterial injection of $\left[{ }^{68} \mathrm{Ga}\right] \mathrm{DOTATATE}$
}

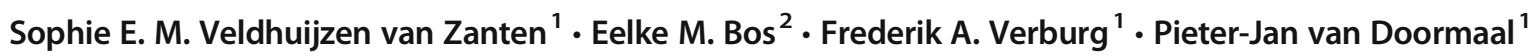

Received: 29 September 2020 / Accepted: 26 October 2020 / Published online: 14 November 2020

(C) The Author(s) 2020

\begin{abstract}
A 40-year-old woman presented with a large intracranial tumour originating from the posterior cerebral falx. After careful evaluation by MRI and angiography, a meningioma was suspected and surgical removal was attempted. The procedure, however, was terminated prematurely due to profuse and uncontrollable bleeding from the tumour. Biopsies taken during surgery revealed a hemangiopericytoma. Radiotherapy was performed with $59.4 \mathrm{~Gy}$, which caused tumour regression and local control for several years. Eventually, the patient progressed and was evaluated for possible peptide receptor radionuclide therapy (PRRT) using $\left[{ }^{68} \mathrm{Ga}\right]$ DOTATATE positron emission tomography/computed tomography (PET/CT), as previously it was described that hemangiopericytoma might show somatostatin receptor expression [1].
\end{abstract}

This article is part of the Topical Collection on Image of the month.

Sophie E. M. Veldhuijzen van Zanten

s.velthuijzenvanzanten@erasmusmc.nl

Frederik A. Verburg

f.verburg@erasmusmc.nl

1 Department of Radiology and Nuclear Medicine, Erasmus MC, Dr. Molewaterplein 40, 3015 GD Rotterdam, The Netherlands

2 Department of Neurosurgery, Erasmus MC, Rotterdam, The Netherlands
As after venous application $\left[{ }^{68} \mathrm{Ga}\right]$ DOTATATE uptake in the majority of the tumour did not exceed the uptake in the liver (i.e. Krenning score 2 [2], panel A), we decided to explore the possibility of increasing the uptake by injection in feeding arteries, as described previously [3-5]. Upon arterial injection in the posterior cerebral artery (Panel B), the mean lesional standardized uptake value increased from 8.4 to 21.0 and the maximum standardized uptake value from 15.8 to 36.0 (Panel C). As a result, the uptake in the entire tumour now exceeds the uptake in the liver (i.e. Krenning score 3, Panel D). This case shows that, especially with arterial application, PRRT can be considered as a serious therapeutic option in this rare disease entity. Our patient's condition unfortunately deteriorated shortly after the diagnostic procedure to a point that therapy with $\left[{ }^{177} \mathrm{Lu}\right]$ DOTATATE was no longer possible. 


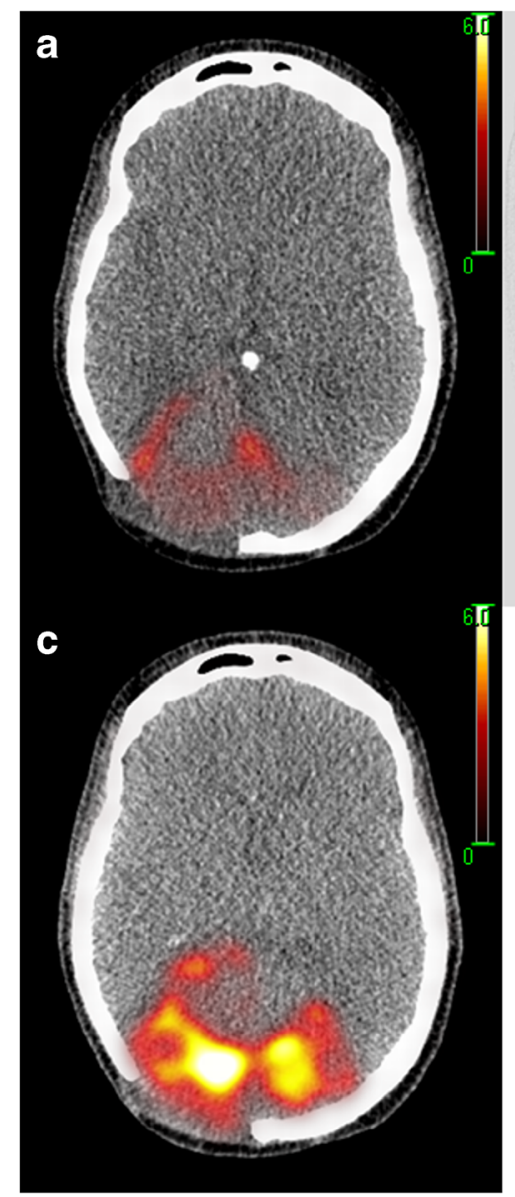

Funding Open access funding provided by University Medical Center Rotterdam (Erasmus MC).

\section{Compliance with ethical standards}

Conflict of interest The authors declare that they have no conflict of interest.

Ethical approval This article does not contain any studies with human participants performed by any of the authors; instead, it describes regular clinical care.

Informed consent As only non-identifying PET/CT and X-ray images are shown here, no informed consent was deemed necessary. In order to fully ascertain anonymity of the patient, the age at presentation was altered slightly without this affecting the essence of the case.

Open Access This article is licensed under a Creative Commons Attribution 4.0 International License, which permits use, sharing, adaptation, distribution and reproduction in any medium or format, as long as you give appropriate credit to the original author(s) and the source, provide a link to the Creative Commons licence, and indicate if changes were made. The images or other third party material in this article are included in the article's Creative Commons licence, unless indicated otherwise in a credit line to the material. If material is not included in the article's Creative Commons licence and your intended use is not permitted by statutory regulation or exceeds the permitted use, you will need to obtain
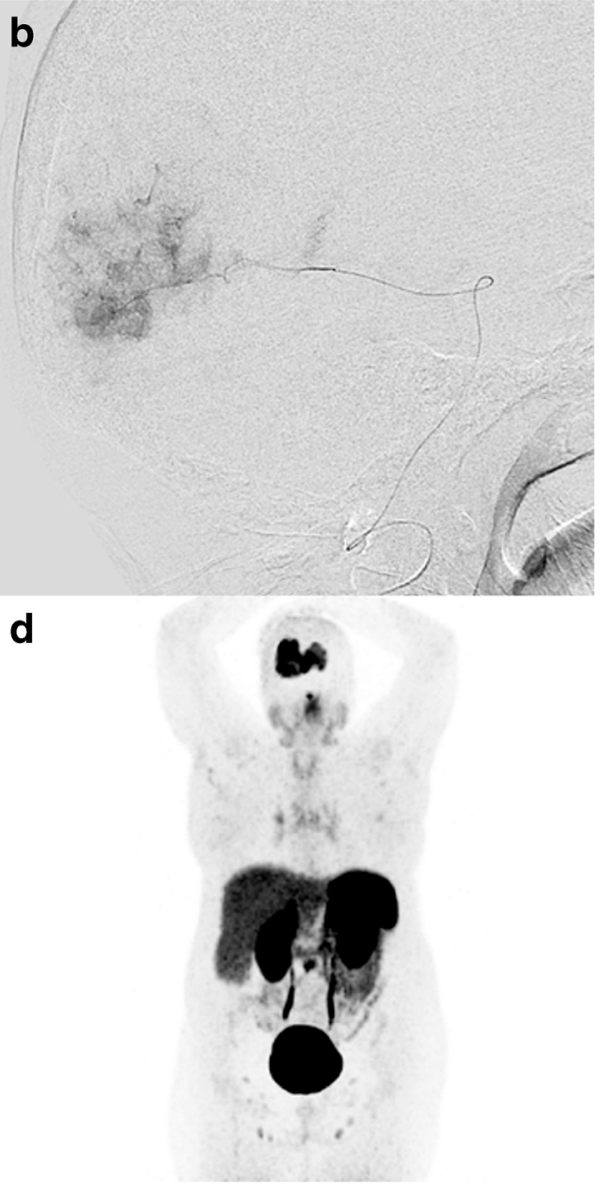

permission directly from the copyright holder. To view a copy of this licence, visit http://creativecommons.org/licenses/by/4.0/.

\section{References}

1. Hung T-J, Macdonald W, Muir T, Celliers L, Al-Ogaili Z. $68 \mathrm{Ga}$ DOTATATE PET/CT of non-FDG-avid pulmonary metastatic hemangiopericytoma. Clin Nucl Med. 2016;41:779-80.

2. Kwekkeboom DJ, Krenning EP. Somatostatin receptor imaging. Semin Nucl Med. 2002;32:84-91.

3. Verburg FA, Wiessmann M, Neuloh G, Mottaghy FM, Brockmann M-A. Intraindividual comparison of selective intraarterial versus systemic intravenous 68Ga-DOTATATE PET/CT in patients with inoperable meningioma. Nuklearmedizin. 2019;58:23-7.

4. Veldhuijzen van Zanten SEM, De Witt Hamer PC, van Dongen GAMS. Brain access of monoclonal antibodies as imaged and quantified by $89 \mathrm{Zr}$-antibody PET: perspectives for treatment of brain diseases. J Nucl Med. 2019;60:615-6.

5. Pruis IJ, van Dongen GAMS, Veldhuijzen van Zanten SEM. The added value of diagnostic and theranostic PET imaging for the treatment of CNS tumors. Int J Mol Sci. 2020;21:1029.

Publisher's note Springer Nature remains neutral with regard to jurisdictional claims in published maps and institutional affiliations. 